Animal Health Research Institute,

Mansora Branch, (Immunology, Biochemistry and Clinical Pathology).

\title{
SEROLOGICAL STUDIES ON MYCOPLASMA GALLISEPTICUM INFECTION IN CHICKENS
}

\author{
(With 12 Tables)
}

By

\section{A.M.E. ASWAY; H.A. SHALABY; K.H. DEEB and M.H.M.A. SHALABY*}

* Dept. of Bacteriology, Animal Health Research Institute, Dokki

(Received at 2/12/2008)

دراسات سيرولوجيه على العدوى بالميكوبلازما جاليسييكم فى الاجاج

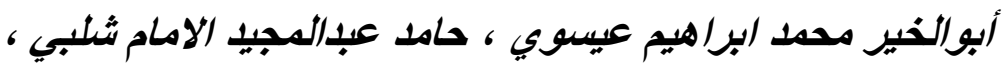

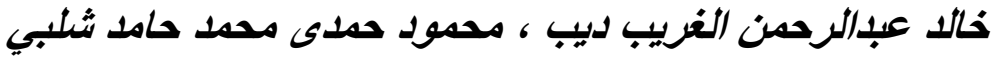

5

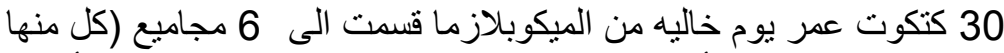

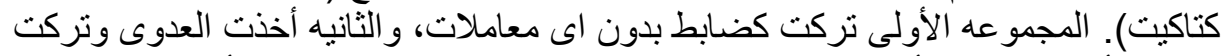

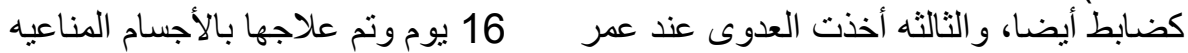

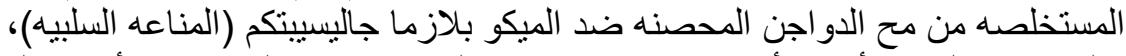

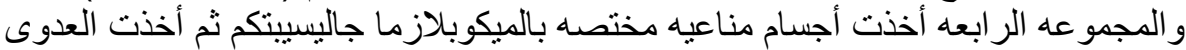

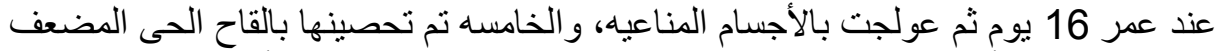

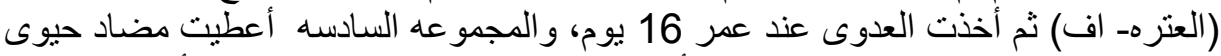

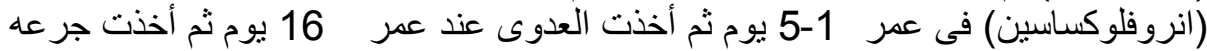

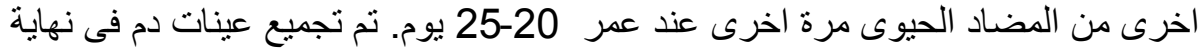

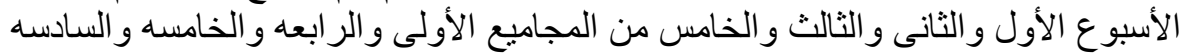

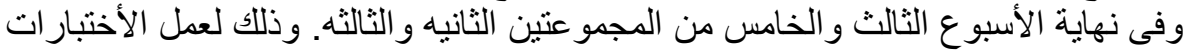

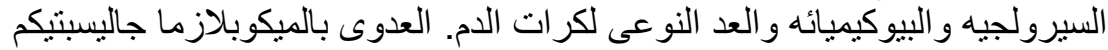

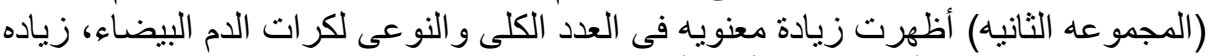

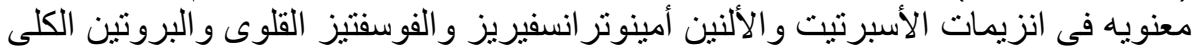

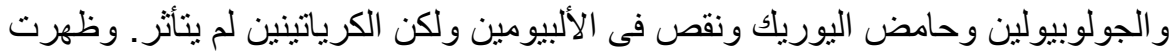

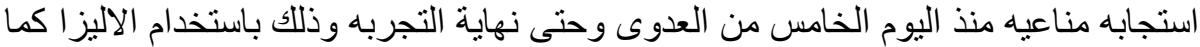

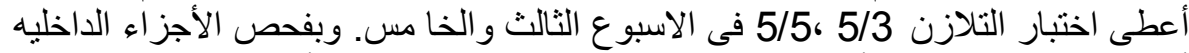

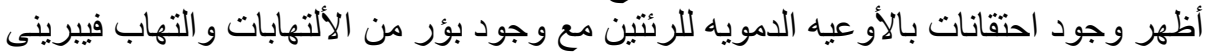

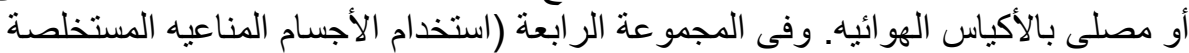

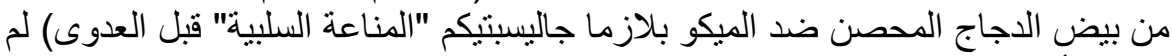

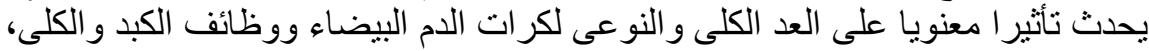

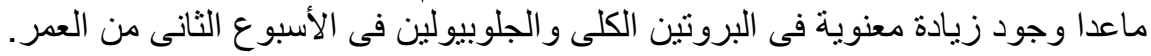




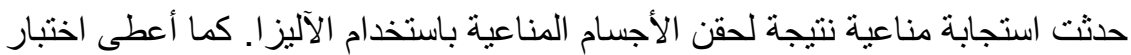

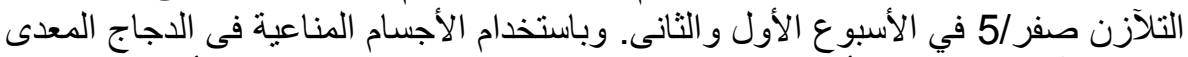

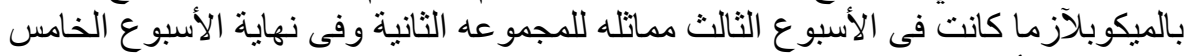

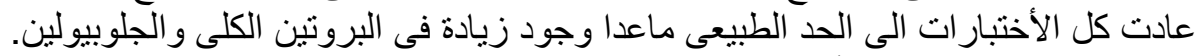

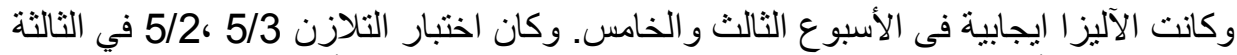

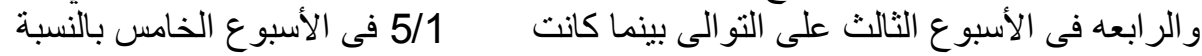

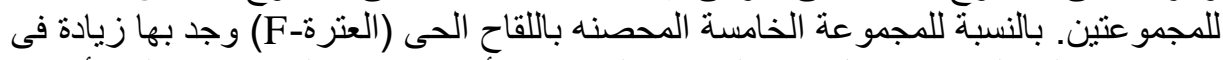

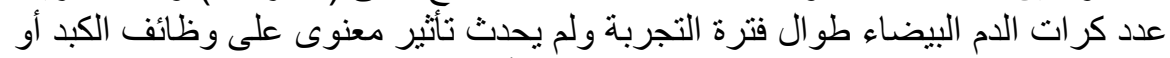

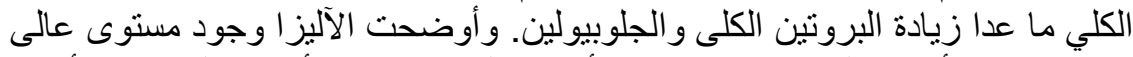

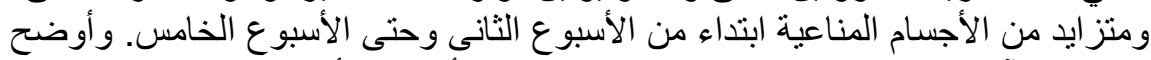

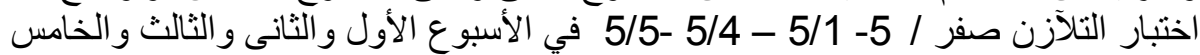

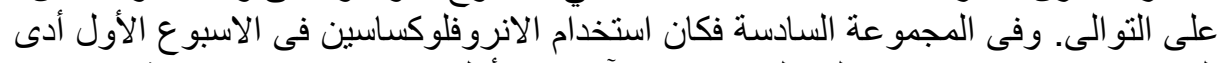

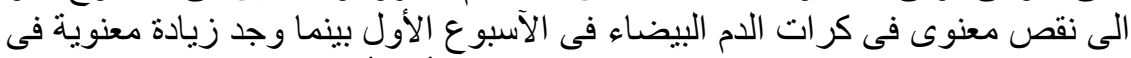

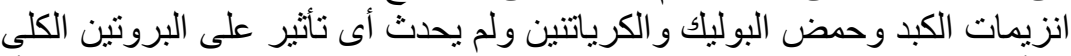

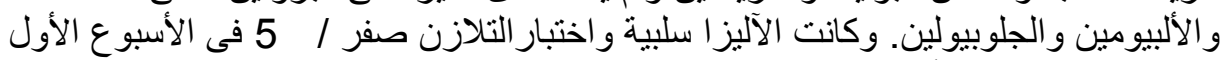

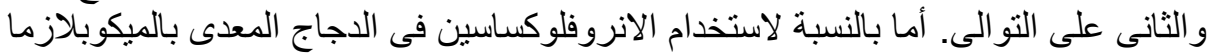

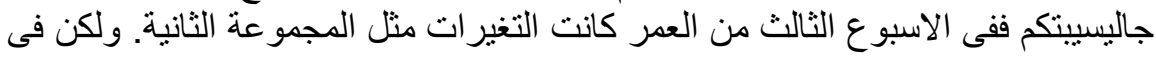

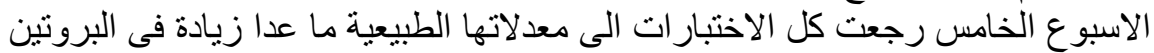

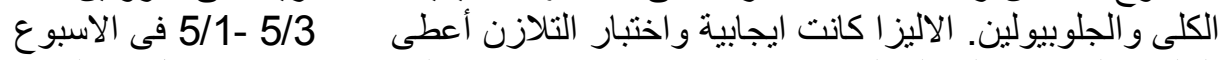

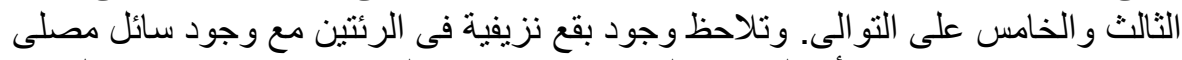

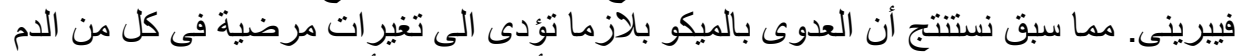

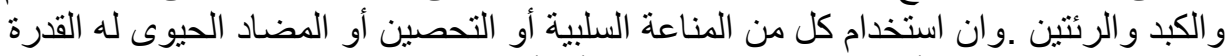

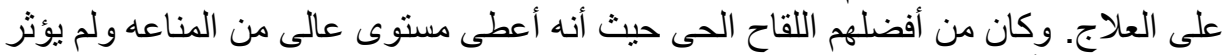

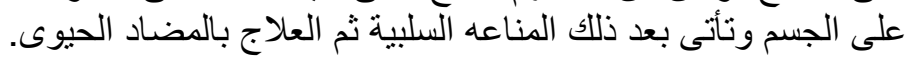

\section{SUMMARY}

30 One day old Mycoplasma free broiler were divided into 6 groups (grs) (each of 5 chicken). The $1^{\text {st }}$ gr. used as control without any treatment, $2^{\text {nd }}$ gr. was infected with Mycoplasma gallisepticum (M.G.) S6 via the thoracic air sac on the $16^{\text {th }}$ day of age and left till the end of the experiment (as infected control gr.), $3^{\text {rd }}$ gr. was infected on the $16^{\text {th }}$ day then passively immunized by I/P injection of egg yolk antibodies $(\mathrm{IgY}), 4^{\text {th }}$ gr. was passively immunized I/P by $(\operatorname{IgY})$ and infected with M.G., then passively immunized, $5^{\text {th }}$ gr. was vaccinated with the living vaccine (F-strain) of M.G. then infected with M.G.S6 and the $6^{\text {th }}$ gr. was orally given the therapeutic dose of enrofloxacin in the drinking water for the $1^{\text {st }} 5$ days of age, then infected with M.G.S6 and the chickens were given another dose of enrofloxacin from $20^{\text {th }}-25^{\text {th }}$ day of age. Blood samples were collected from each bird in grs. (1, 4, 5 and 6) at the 
end of the $1^{\text {st }}, 2^{\text {nd }}, 3^{\text {rd }}$ and $5^{\text {th }}$ weeks of age and from grs. ( 2 and 3 ) at the end of the $3^{\text {rd }}$ and $5^{\text {th }}$ weeks for serological, hematological and biochemical tests. The lungs, trachea and air sacs were collected for the isolation of M.G. The infected birds gr. (2) revealed Leukocytosis, heterophilia and monocytosis in the $3^{\text {rd }}$ and $5^{\text {th }}$ weeks of age. There was a highly signififent increase in the AST, ALT, AP, Total proteins, globulin and uric acid. The serum albumin was decreased, while the creatinine not significant changed. The ELISA showed positive values as early as the $5^{\text {th }}$ day post infection (PI) till the end of the experiment. The result of serum plate agglutination test (SPA) illustrated $3 / 5$ and $5 / 5$ at the end of the $3^{\text {rd }}$ and $5^{\text {th }}$ weeks of the age respectively. The Pulmonary tissue was congested and showed focal pneumonic areas. The passively immunized birds of gr. (4), before infection, showed non-significant change in leukogram but there are a significant increase in the total protein and globulin at the end of the $2^{\text {nd }}$ week. There was a positive result of the EILSA due to the injected (Ig). The SPA was 0/5 and 0/5 in the $1^{\text {st }}$ and $2^{\text {nd }}$ weeks of age respectively. The passively immunized and infected chickens grs. (3\&4) showed similar results to gr. (2) at the end of the $3^{\text {rd }}$ week. All the parameters returned to nearly the normal value in the $5^{\text {th }}$ week of age except for a significant increase in the serum total protein and globulin. The ELISA showed a positive result in the $3^{\text {rd }}$ and $5^{\text {th }}$ weeks of age. The SPA showed $3 / 5$ and $2 / 5$ in grs. (3\&4) respectively in the $3^{\text {rd }}$ week and $1 / 5$ in the $5^{\text {th }}$ week of age in both grs. The actively immunized birds of gr. (5) showed leukocytosis, heterophilia, lymphocytosis and monocytosis at the end of the $1^{\text {st }}, 2^{\text {nd }}, 3^{\text {rd }}$ and $5^{\text {th }}$ weeks of age. All the parameters were not significantly changed except the total proteins and globulin which showed highly significant increase. The ELISA was gradually increased from the $2^{\text {nd }}$ till the $5^{\text {th }}$ week of age. The SPA showed $0 / 5,1 / 5,4 / 5$ and $5 / 5$ in the $1^{\text {st }}, 2^{\text {nd }}, 3^{\text {rd }}$ and $5^{\text {th }}$ weeks of age respectively. The enrofloxacin treated birds gr. (6) before infection especially at the end of the $1^{\text {st }}$ week of age, showed leukopenia, heterophilia, lymphopenia and a significant increase in AST, ALT, AP, uric acid and creatinine. Meanwhile, the serum total proteins, albumin and globulin were non-significantly changed. The ELISA showed nonsignificant change. The SPA is 0/5in the $1^{\text {st }} \& 2^{\text {nd }}$ weeks of age. The enrofloxacin treated birds gr. (6) after infection and at the end of the $3^{\text {rd }}$ week of age showed similar hematological finding to gr. (2) at the end of the $5^{\text {th }}$ week of age. All parameters nearly regained to their normal values except for a significant increase in the total proteins and globulin. The ELISA showed a significant increase. The SPA were 3/5 and 1/5 at 
the end of the $3^{\text {rd }} \& 5^{\text {th }}$ weeks respectively. The chickens which were sacrificed at the end of the $3^{\text {rd }}$ week, revealed focal hemorrhage in the lung and serofibrinous exudates. It is recommended to vaccinate the chickens with F-strain living vaccine of M.G.

Key words: Mycoplasma gallisepticum, chickens, immunology

\section{INTRODUCTION}

M.G. infections can cause significant economic losses on poultry farms from chronic respiratory disease, reduce feed efficiency, decreased growth and decreased egg production. The carcasses of birds send to slaughter may also be down graded. M.G. infections are notifable to the World Organization for Animal Health (2007). M.G. infection vary from asymptomic to sever, depending on the infecting strains and other factors. More sever infections are seen when the birds are infected concurrently with New-Castle disease virus, infectious bronchitis virus E. coli or other pathogens World Organization for Animal Health (2007). M.G. is the most economically significant mycoplasma pathogen of poultry, and has a world wide distribution. Phenotypic variation of major surface antigens occurs at high frequency, which is probable explanation for chronic infection by M.G. despite of strong immune response (Levisohn and Kleven, 2000). The presence of M.G. predisposes birds to other infections which together causes mortality, poor growth and condemnation of the carcasses (Kempf et al., 1992).

Efforts to reduce the effect of the disease on infected layers have included the use of antibiotics or vaccination (Robert et al., 2001). Vaccination is an option for controlling M.G. when the security measures fail to prevent the infection of poultry with M.G. (Jordan, 1979). There are two types of vaccination, killed vaccines (bacterins) and living vaccines which include F-strain, TS-11 and 6/85 strain (Whithear, 1996). The most attractive application of $\operatorname{IgY}$ in the passive immunization therapy. At present several researchers reported that administration of IgY is quite effective in prevention of Rota viral diarrhea and enterotoxaemia E. coli infection (Yamamoto et al., 1997). The antibodies have been used for over a century in the prevention and treatment of infectious diseases. Antibody treatment of the lower respiratory tract infection has a long history of success and is receiving renewed interest (Margaret and Richard, 2000). The yolk of eggs laid by immunized chickens has been widely recognized as an excellent source of polyclonal antibodies for over a decade (Jensenius and Koch, 1997). 
The antibiotic therapy is another option for controlling losses associated with mycoplasmosis. Several therapeutic antibiotics with activity against mycoplasma were approved for use in poultry. Such antibiotics include Fluoroquinolone group which include enrofloxacin, amifloxacin, ciprofloxacin, danofloxacin, difloxacin, marboflxacin, ofloxacin and norfloxcin (Calnek et al., 1997). Antimicrobial drugs are used in feed-producing animals to treat, prevent and control disease and to improve growth and feed efficiency. Fluoroquinolones are a modern group of antibiotics which are active against wide range of gramnegative, gram-positive and cytoplasma spp. (Abo El-Nile, 1997).

The present work was planned for evaluation of 3 methods, passive immunization (using egg yolk antibodies [IgY]) active immunization (using F-strain living vaccine) and treatment with antibiotics (enrofloxacin) to control M.G. infection. Such evaluation was based on the hematological, biochemical and immunological changes.

\section{MATERIALS and METHODS}

Antigen preparation of M.G.: It was prepared for vaccination of laying hens for production of antibodies specific for M.G. in egg yolk, for ELISA and Western-blotting techniques. It was prepared according to (Patten et al., 1984).

Determination of protein content of crude antigen: It was determined to calculate the optimum dose of antigen for inoculation of laying hens for active immunization and concentration of antigen used for ELISA and Western-blotting techniques. It was estimated colorimetrically according to Lowry et al. (1951).
Concentration $=$
O.D. of sample
O.D. of standard
$\mathrm{x}$ concentration of standard

Hens for production of egg yolk antibodies (IgY): 10 hens (5 month old) mycoplasma free used for the production of specific $\operatorname{IgY}$ against M.G. used for passive immunization, Separation and purification of IgY from chicken egg yolk. This procedure was done according to (Jensenius and koch, 1997). Sodium dodecyl sulphate - polyacrylamide Gel-electrophoresis (SDS-PAGE): It was done according to Towbin, et al. (1979) and Charmbach (1985) for the determination of the specificity of the produced IgY against M.G. 
Experimental chickens: 32 one day old, mycoplasma free broiler chickens were obtained from Cairo Comp. for poultry. The chickens were housed in disinfected cages under controlled hygienic measures. They were feed on (starter, grower and finisher) free of mycotoxins and antimicrobial agents ration. All chickens were vaccinated with Hitchiner B 1 and Lasota for New-Castle disease (Main biological laboratories "mbl" USA) at the age of 7, 21 and 28 day and Bursal disease vaccine for Gumboro "mbl" at the age of 14 day via the drinking water. The mycoplasma free status of chicken was confirmed by serological examination of 2 chickens using serum slid agglutination test (Stipkovits, 1997).

Mycoplasma gallisepticum strain: The experimental infection was done by M.G.S6 (culture diagnostic lab. Corenell University Ithaco New York, USA, Each ml contain $\left.3 \times 10^{7} \mathrm{cfu}\right)$.

Living vaccine (F-strain): M.G. live vaccine, avian isolate F-vax M.G. (Sherring Plough Animal Health Com.). It was used for active immunization of chickens in this study.

Drugs: Enrofloxacin was obtained from BAYER Com. the recommended therapeutic dose was $10 \mathrm{mg} / \mathrm{kg} . \mathrm{b}$. weight of drinking water for 3-5 day (Ahmed, 1996).

Experimental design: 32 one day old, Mycoplasma free broiler chickens were used. 2 chickens were used for confirmation of the mycoplasma free status and 30 chickens were divided into 6 groups (grs.) each of 5 chickens. The $1^{\text {st }}$ gr. kept as control (co.) without any treatment, the $2^{\text {nd }}$ gr. Kept as infected co. (infected with $0.1 \mathrm{ml} \mathrm{M.G.} \mathrm{broth} \mathrm{culture}$ containing $3 \times 10^{7} \mathrm{cfu} / \mathrm{ml}$ (Stipkovits, 1997) at the age of 16 days via the posterior thoracic airsac), the $3^{\text {rd }}$ gr. were infected with M.G.as in gr. 2, then passively immunized intraperitonly (I/P) with $\mathrm{IgY}(0.7 \mathrm{gm}$ of egg yolk antibodies powder reconstituted in $0.5 \mathrm{ml}$ PBS) at the age of 20, 24, 28 and 32 days, the $4^{\text {th }}$ gr. Were passively immunized with $0.5 \mathrm{ml}$ of M.G. IgY on the $1^{\text {st }}, 5^{\text {th }}, 9^{\text {th }}$ and $13^{\text {th }}$ days of age, these chickens were infected on the $16^{\text {th }}$ day of age with M.G. then passively immunized on the $20^{\text {th }}, 24^{\text {th }}, 28^{\text {th }}$ and $32^{\text {nd }}$ days of age. The $5^{\text {th }}$ gr. were vaccinated with $0.02 \mathrm{ml}$ of F-strain living vaccine of M.G. on the $1^{\text {st }}$ day of age $\left(1 \times 10^{5} \mathrm{cfu} / \mathrm{ml}\right)$ via intranasal $(\mathrm{I} / \mathrm{N})$ installation (Rodriguez and Kleven, 1980; Kleven, et al., 1984), those chickens were infected on the $16^{\text {th }}$ day of age with M.G.. The $6^{\text {th }}$ gr. were orally administered the therapeutic dose of enrofloxacin in drinking water for the $1^{\text {st }} 5$ days of age, then infected on the $16^{\text {th }}$ day of age with M.G. and then given another dose of enrofloxacin $\left(1 \mathrm{ml} / 2\right.$ liter) from $20^{\text {th }}-25^{\text {th }}$ day of age. 
Blood samples were collected at the end of $1^{\text {st }}, 2^{\text {nd }}, 3^{\text {rd }}$ and $5^{\text {th }}$ weeks of age in grs. $1,4,5$ and 6 while in grs. $2 \& 3$ the samples were collected at the end of the $3^{\text {rd }} \& 5^{\text {th }}$ weeks only. 2 blood samples were collected from each bird. The $1^{\text {st }}$ samples were used for hematological (leukocytic \& differential counts) studies (Nutt and Herrick, 1952, Coles, 1986). The $2^{\text {nd }}$ samples for serum separation to be used for serological identification using ELISA (Engvall and perlmann, 1981) and slide agglutination test (Adler and Yamamoto, 1956 and Stipkovits, 1997) and biochemical tests using Kits of Diamond \& Human. Serum Alkaline phosphates (AP) (Belfield and Goldberg, 1971), aspartate aminotransferase (AST) and alanine aminotranferase (ALT) (Reitman and Frankel, 1957), serum total protein (Henry, 1974), serum albumin (Doumas, 1971), serum globulin (Doumas and Biggs, 1972), serum uric acid (Fossati, 1980) and serum creatinine (Henry, 1979). The chickens were sacrificed at the end of the $1^{\text {st }}, 2^{\text {nd }}, 3^{\text {rd }}$ and $5^{\text {th }}$ weeks of age after blood sampling. the lungs, trachea and air sacs were collected for the reisolation of M.G. after (Stipkovits, 1997) and identification of the isolated M.G. according to (Clyde, 1983). The obtained data were statistically analysed according to (Fisher, 1953).

\section{RESULTS}

Table 1: Leukogram of chickens in grs. $(1,4,5 \& 6)$ at the end of the $1^{\text {st }}$ week of age.

\begin{tabular}{|l|l|l|l|l|l|}
\hline Groups & \multirow{2}{*}{$\begin{array}{l}\text { T.L. C. } \\
\text { (thousand/ul) }\end{array}$} & \multicolumn{4}{l|}{ Differential T .L. C . (thousand/ul) } \\
\cline { 3 - 6 } & & Heterophils & Lymphocytes & Eosinophils & Monocytes \\
\hline Control & $27.47+1.25$ & $6.25+0.50$ & $19.75+0.95$ & $0.95+0.10$ & $0.52+0.02$ \\
\hline $\begin{array}{l}\text { Passive } \\
\text { immunization }\end{array}$ & $31.81+0.90$ & $7.35+0.28$ & $22.71+0.75$ & $1.05+0.03$ & $0.70+0.12$ \\
\hline $\begin{array}{l}\text { Active } \\
\text { Immunization }\end{array}$ & $43.03+2.10$ & $11.25+2.10$ & $28.45+1.65$ & $1.08+0.15$ & $1.25+0.15$ \\
\hline $\begin{array}{l}\text { Enrofloxacin } \\
\text { treatment }\end{array}$ & $22.73+0.95$ & $8.50+0.57$ & $12.95+0.95$ & $0.75+0.16$ & $0.53+0.09$ \\
\hline
\end{tabular}

T .L.C. $=$ total leukocytic count $\mathrm{P}<0.05$

Table 2: Leukogram of chickens in grs. $(1,4,5 \& 6)$ at the end of the $2^{\text {nd }}$ week of age.

\begin{tabular}{|l|l|l|}
\hline Groups & T .L. C. & Differential T.L.C. (thousand/ul) \\
\hline
\end{tabular}


Assiut Vet. Med. J. Vol. 55 No. 120 January 2009

\begin{tabular}{|l|c|c|c|c|c|}
\hline & (thousand/ul) & Heterophils & Lymphocytes & Eosinophils & Monocytes \\
\hline Control & $28.52+0.25$ & $6.41 .+0.25$ & $21.35+0.55$ & $0.75+.025$ & $1.01+0.30$ \\
\hline $\begin{array}{l}\text { Passive } \\
\text { immunization }\end{array}$ & $30.95+0.72$ & $6.45+0.55$ & $21.75+0.65$ & $1.05+0.03$ & $0.89+0.12$ \\
\hline $\begin{array}{l}\text { Active } \\
\text { Immunization }\end{array}$ & $40.12+3.25$ & $9.07+0.35$ & $28.65+1.95$ & $1.20+0.35$ & $1.20+0.20$ \\
\hline $\begin{array}{l}\text { Enrofloxacin } \\
\text { treatment }\end{array}$ & $28.07+1.02$ & $6.75+019$ & $19.55+1.05$ & $0.75+0.10$ & $1.02+0.03$ \\
\hline
\end{tabular}

Table 3: Liver function tests of chicken in groups $(1,4,5$ and 6) at the end of $1^{\text {st }}$ week of age.

\begin{tabular}{|c|c|c|c|c|c|c|}
\hline Groups & AST $(\mathrm{u} / \mathrm{l})$ & ALT $(\mathrm{u} / \mathrm{l})$ & $\mathrm{AP}(\mathrm{u} / \mathrm{l})$ & $\begin{array}{c}\text { T.P. } \\
(\mathrm{gm} / \mathrm{dl})\end{array}$ & $\begin{array}{c}\text { Albumin } \\
(\mathrm{gm} / \mathrm{dl})\end{array}$ & $\begin{array}{c}\text { Globulin } \\
(\mathrm{gm} / \mathrm{dl})\end{array}$ \\
\hline Control & $85.75+2.45$ & $70.05+1.55$ & $234.45+4.35$ & $3.95+0.19$ & $1.98+0.12$ & $1.16+0.12$ \\
\hline $\begin{array}{c}\text { Passive } \\
\text { immunization }\end{array}$ & $86.05+1.01$ & $66.75+4.25$ & $240.30+4.90$ & $4.25+0.10$ & $3.01+0.03$ & $1.75+0.11$ \\
\hline $\begin{array}{c}\text { Active } \\
\text { immunization }\end{array}$ & $85.85+3.40$ & $69.99+0.95$ & $249.85+2.75$ & $4.15+0.10$ & $3.01+0.11$ & $1.05+0.25$ \\
\hline $\begin{array}{c}\text { Enrofloxacin } \\
\text { Treatment }\end{array}$ & $92.00+3.00$ & $79.85+2.35$ & $255.09+3.95$ & $4.25+0.18$ & $2.98+0.02$ & $1.37+0.14$ \\
\hline
\end{tabular}

AST $=$ Aspartate aminotransferase

ALT $=$ alanine aminotransferas

$\mathrm{AP}=$ alkaline phosphatase

T.P =total proteine

Table 4: Liver function tests of chicken in groups $(1,4,5$ and 6$)$ at the end of $2^{\text {nd }}$ week of age.

\begin{tabular}{|c|c|c|c|c|c|c|}
\hline Groups & AST $(\mathrm{u} / \mathrm{l})$ & ALT $(\mathrm{u} / \mathrm{l})$ & $\mathrm{AP}(\mathrm{u} / \mathrm{l})$ & $\begin{array}{c}\text { T.P. } \\
(\mathrm{gm} / \mathrm{dl})\end{array}$ & $\begin{array}{c}\text { Albumin } \\
(\mathrm{gm} / \mathrm{dl})\end{array}$ & $\begin{array}{c}\text { Globulin } \\
(\mathrm{gm} / \mathrm{dl})\end{array}$ \\
\hline Control & $85.25+2.15$ & $65.10+1.85$ & $235.75+1.69$ & $3.50+0.20$ & $1.95+0.20$ & $1.55+0.11$ \\
\hline $\begin{array}{c}\text { Passive } \\
\text { Immunization }\end{array}$ & $87.20+3.10$ & $69.85+2.10$ & $238.78+1.11$ & $4.85+0.10$ & $2.62+0.07$ & $2.55+0.15$ \\
\hline $\begin{array}{c}\text { Active } \\
\text { immunization }\end{array}$ & $79.95+3.45$ & $71.82+2.95$ & $241.45+1.43$ & $3.89+0.02$ & $1.85+0.09$ & $2.04+0.09$ \\
\hline $\begin{array}{c}\text { Enrofloxa-cin } \\
\text { treatment }\end{array}$ & $85.95+1.21$ & $72.65+1.30$ & $240.64+1.31$ & $3.90+0.25$ & $2.01+0.25$ & $1.89+0.15$ \\
\hline
\end{tabular}

Table 5: Some Kidney function tests of chickens in groups $(1,4,5$ and 6) at the end of the $1^{\text {st }}$ and $2^{\text {nd }}$ week of age.

\begin{tabular}{|c|c|c|}
\hline Group & $1^{\text {st }}$ week & $2^{\text {nd }}$ week \\
\hline
\end{tabular}


Assiut Vet. Med. J. Vol. 55 No. 120 January 2009

\begin{tabular}{|c|c|c|c|c|}
\hline & $\begin{array}{c}\text { Uric acid } \\
(\mathrm{mg} / \mathrm{dl})\end{array}$ & $\begin{array}{c}\text { Creatinine } \\
(\mathrm{mg} / \mathrm{dl})\end{array}$ & $\begin{array}{c}\text { Uric acid } \\
(\mathrm{mg} / \mathrm{dl})\end{array}$ & $\begin{array}{c}\text { Creatinine } \\
(\mathrm{mg} / \mathrm{dl})\end{array}$ \\
\hline Control & $4.90+0.15$ & $0.75+0.03$ & $4.08+0.15$ & $0.88+0.02$ \\
\hline $\begin{array}{c}\text { Passive } \\
\text { immunization }\end{array}$ & $7.95+0.14$ & $0.89+.02$ & $4.25+0.35$ & $0.90+0.03$ \\
\hline $\begin{array}{c}\text { Active } \\
\text { immunization }\end{array}$ & $5.01+60.35$ & $0.71+0.03$ & $5.09+0.15$ & $0.75+0.01$ \\
\hline $\begin{array}{c}\text { Enrofloxacin } \\
\text { treatment }\end{array}$ & $5.95+0.43$ & $0.99+0.01$ & $4.85+0.12$ & $0.70+0.02$ \\
\hline
\end{tabular}

$\mathrm{P}<0.05$

Table 6: Leukogram of the chickens in groups (1-6)at the end of the $3^{\text {rd }}$ week of age.

\begin{tabular}{|l|c|c|c|c|c|}
\hline \multirow{2}{*}{ Groups } & T. L. C. & \multicolumn{4}{|c|}{ Differential T.L.C. (thousand / ul ) } \\
\cline { 3 - 6 } & (thousand/ul) & Heterophils & Lymphocyts & Eosinophils & Monocytes \\
\hline CO. & $29.80+1.49$ & $9.25+0.75$ & $18.95+1.73$ & $0.95+0.25$ & $0.65+0.02$ \\
\hline CO.+Inf. & $46.26+1.53$ & $15.25+1.11$ & $28.75+1.40$ & $1.35+0.02$ & $0.91+0.03$ \\
\hline Inf.+ Pass.Imm.. & $40.74+1.75$ & $12.95+1.20$ & $26.95+2.39$ & $1.09+0.18$ & $1.75+0.07$ \\
\hline Pass.Imm.+Inf.+Pass.Imm. & $35.46+1.59$ & $7.03+1.20$ & $25.59+1.80$ & $1.39+0.07$ & $1.45+0.06$ \\
\hline Active Imm.+ Inf. & $38.95+0.55$ & $8.25+1.04$ & $27.85+1.12$ & $1.30+0.19$ & $1.55+0.01$ \\
\hline Enro.+Inf. +Enro. & $44.40+1.55$ & $16.50+0.95$ & $25.09+1.99$ & $1.66+0.07$ & $1.15+0.02$ \\
\hline
\end{tabular}

CO.=control Inf. $=$ infection Pass. $=$ passive Imm.=immunization. $\mathrm{P}<0.05$

Enro.= Enrofloxacin

Table 7: Leukogram of the chickens in groups (1-6) at the end of the $5^{\text {th }}$ week of age.

\begin{tabular}{|l|c|c|c|c|c|}
\hline \multirow{2}{*}{ Groups } & T. L. C. & \multicolumn{4}{|c|}{ Differential T.L.C. (thousand / ul ) } \\
\cline { 3 - 6 } & (thousand/ul) & Heterophils & Lymphocyts & Eosinophils & Monocytes \\
\hline CO. & $29.48+2.05$ & $9.05+0.75$ & $18.45+1.35$ & $0.79+0.25$ & $1.09+0.25$ \\
\hline CO.+Inf. & $45.54+0.85$ & $14.75+1.07$ & $26.99+1.15$ & $0.85+0.07$ & $2.95+0.03$ \\
\hline Inf.+ Pass.Imm.. & $32.75+1.50$ & $9.75+0.75$ & $21.04+1.09$ & $0.99+0.06$ & $0.97+0.25$ \\
\hline Pass.Imm.+Inf.+Pass.Imm. & $31.94+0.75$ & $10.25+0.76$ & $20.11+.15$ & $0.59+0.02$ & $0.99+0.21$ \\
\hline Active Imm.+ Inf. & $36.79+1.15$ & $7.59+1.05$ & $22.35+1.55$ & $1.15+0.06$ & $0.70+0.02$ \\
\hline Enro.+Inf. +Enro. & $32.32+0.70$ & $9.07+0.75$ & $21.45+0.75$ & $0.95+0.10$ & $0.85+0.11$ \\
\hline
\end{tabular}

Table 8: Liver function tests of chickens in groups (1-6) at the end of the $3^{\text {rd }}$ week. 
Assiut Vet. Med. J. Vol. 55 No. 120 January 2009

\begin{tabular}{|l|c|c|c|c|c|c|}
\hline \multicolumn{1}{|c|}{ Groups } & $\begin{array}{c}\text { AST } \\
(\mathrm{u} / \mathrm{l})\end{array}$ & $\begin{array}{c}\text { ALT } \\
(\mathrm{u} / \mathrm{l})\end{array}$ & $\begin{array}{c}\text { AP } \\
(\mathrm{u} / \mathrm{l})\end{array}$ & $\begin{array}{c}\text { T.P. } \\
(\mathrm{gm} / \mathrm{dl})\end{array}$ & $\begin{array}{c}\text { Albumin } \\
(\mathrm{gm} / \mathrm{dl}\end{array}$ & $\begin{array}{c}\text { Globulin } \\
(\mathrm{gm} / \mathrm{dl})\end{array}$ \\
\hline CO. & $89.45+3.75$ & $76.05+2.95$ & $249.50+5.09$ & $4.15+0.29$ & $1.99+0.15$ & $2.16+0.25$ \\
\hline CO.+Inf. & $127.15+076$ & $89.55+1.16$ & $280.75+4.85$ & $5.70+0.21$ & $1.95+0.19$ & $3.75+0.20$ \\
\hline $\begin{array}{l}\text { Inf.+ } \\
\text { Pass.Imm.. }\end{array}$ & $103.75+2.80$ & $85.07+1.19$ & $260.77+5.11$ & $4.84+0.75$ & $1.85+0.09$ & $2.99+0.50$ \\
\hline $\begin{array}{l}\text { Pass.Imm.+Inf. } \\
+ \text { Pass.Imm. }\end{array}$ & $99.95+2.95$ & $83.09+1.75$ & $259.30+5.12$ & $5.66+0.19$ & $2.01+0.25$ & $3.65+0.03$ \\
\hline $\begin{array}{l}\text { Active Imm.+ } \\
\text { Inf. }\end{array}$ & $90.85+2.95$ & $81.02+1.91$ & $250.95+1.49$ & $4.94+0.25$ & $1.95+0.25$ & $2.99+0.25$ \\
\hline $\begin{array}{l}\text { Enro.+Inf. } \\
\text { +Enro. }\end{array}$ & $119.45+3.75$ & $89.11+2.10$ & $271.53+5.85$ & $5.70+0.45$ & $1.95+0.19$ & $3.75+0.15$ \\
\hline
\end{tabular}

AST $=$ aspartate aminotransferase $\quad$ ALT $=$ alanin aminotransferase $\quad \mathrm{T} . \mathrm{P} .=$ total protein $\mathrm{AP}=$ alkalin phosphates'

$\mathrm{P}<0.05$

Table 9: Liver function tests of chickens in groups (1-6) at the end of the $5^{\text {th }}$ week.

\begin{tabular}{|l|c|c|c|c|c|c|}
\hline \multicolumn{1}{|c|}{ Groups } & $\begin{array}{c}\text { AST } \\
(\mathrm{u} / \mathrm{l})\end{array}$ & $\begin{array}{c}\text { ALT } \\
(\mathrm{u} / \mathrm{l})\end{array}$ & $\begin{array}{c}\text { AP } \\
(\mathrm{u} / \mathrm{l})\end{array}$ & $\begin{array}{c}\text { T.P. } \\
(\mathrm{gm} / \mathrm{dl})\end{array}$ & $\begin{array}{c}\text { Albumin } \\
(\mathrm{gm} / \mathrm{dl}\end{array}$ & $\begin{array}{c}\text { Globulin } \\
(\mathrm{gm} / \mathrm{dl})\end{array}$ \\
\hline CO. & $85.62+1.55$ & $70.65+5.75$ & $251.11+12.35$ & $3.94+0.35$ & $1.95+0.19$ & $1.99+0.11$ \\
\hline CO.+Inf. & $130.75+1.45$ & $88.45+1.60$ & $281.16+4.35$ & $6.30+0.25$ & $1.95+0.12$ & $4.35+0.15$ \\
\hline Inf.+ Pass.Imm.. & $86.10+1.05$ & $75.46+1.73$ & $261.11+2.49$ & $4.84+0.01$ & $1.99+0.09$ & $2.85+0.09$ \\
\hline $\begin{array}{l}\text { Pass.Imm.+Inf.+ } \\
\text { Pass.Imm. }\end{array}$ & $83.39+3.15$ & $71.45+0.97$ & $255.17+2.50$ & $4.07+0.12$ & $2.12+0.23$ & $1.95+0.17$ \\
\hline $\begin{array}{l}\text { Active Imm.+ } \\
\text { Inf. }\end{array}$ & $81.25+1.95$ & $69.45+2.35$ & $255+951.25$ & $4.94+0.19$ & $1.95+0.09$ & $2.99+0.10$ \\
\hline $\begin{array}{l}\text { Enro.+Inf. } \\
+ \text { Enro. }\end{array}$ & $85.95+2.85$ & $75.35+1.15$ & $260.59+2.55$ & $4.86+0.05$ & $2.01+0.05$ & $2.85+0.05$ \\
\hline \multicolumn{1}{|c|}{$<0.05$} & & & & & \\
\hline
\end{tabular}

$\mathrm{P}<0.05$

Table 10: Kidney function tests of chickens in groups (1-6) at the end of the $3^{\text {rd }}$ and $5^{\text {th }}$ weeks.

\begin{tabular}{|c|c|c|c|c|}
\hline \multirow{2}{*}{ Groups } & \multicolumn{2}{|c|}{ The end of the $3^{\text {rd }}$ week } & \multicolumn{2}{|c|}{ The end of the $5^{\text {th }}$ week } \\
\cline { 2 - 5 } & $\begin{array}{c}\text { Uric acid } \\
(\mathrm{mg} / \mathrm{dl})\end{array}$ & $\begin{array}{c}\text { Creatinine } \\
(\mathrm{mg} / \mathrm{dl})\end{array}$ & $\begin{array}{c}\text { Uric acid } \\
(\mathrm{mg} / \mathrm{dl})\end{array}$ & $\begin{array}{c}\text { Creatinine } \\
(\mathrm{mg} / \mathrm{dl})\end{array}$ \\
\hline CO. & $5.00+0.15$ & $0.85+0.08$ & $3.95+0.15$ & $0.81+0.05$ \\
\hline CO.+Inf. & $5.95+0.09$ & $0.90+0.02$ & $9.11+0.19$ & $0.81+0.09$ \\
\hline Inf.+ Pass.Imm.. & $4.90+0.08$ & $0.85+0.03$ & $4.59+0.13$ & $0.89+0.06$ \\
\hline $\begin{array}{c}\text { Pass.Imm.+Inf.+ } \\
\text { Pass.Imm. }\end{array}$ & $5.02+0.10$ & $0.88+0.06$ & $4.25+0.15$ & $0.75+0.05$ \\
\hline Active Imm.+ Inf. & $4.85+0.15$ & $0.79+0.07$ & $4.15+0.11$ & $0.73+0.09$ \\
\hline Enro.+Inf. +Enro. & $5.09+0.25$ & $0.83+0.03$ & $4.19+0.08$ & $0.80+0.03$ \\
\hline
\end{tabular}

Table 11: Results of ELISA in the chickens of groups (1-6). 
Assiut Vet. Med. J. Vol. 55 No. 120 January 2009

\begin{tabular}{|l|c|c|c|c|}
\hline \multicolumn{1}{|c|}{$\begin{array}{l}\text { Age in week } \\
\text { Groups }\end{array}$} & $1^{\text {st }}$ week & $2^{\text {nd }}$ week & $3^{\text {rd }}$ week & $5^{\text {th }}$ week \\
\hline CO. & $0.05+0.01$ & $0.08+0.03$ & $0.10+0.01$ & $0.15+0.01$ \\
\hline CO.+Inf. & 0 & 0 & $0.15+0.01$ & $1.25+0.15$ \\
\hline $\begin{array}{l}\text { Inf.+ } \\
\text { Pass.Imm.. }\end{array}$ & 0 & 0 & $0.17+0.02$ & $0.75+0.02$ \\
\hline $\begin{array}{l}\text { Pass.Imm.+Inf. } \\
+ \text { Pass.Imm. }\end{array}$ & $0.11+0.02$ & $0.18+0.02$ & $0.22+0.01$ & $0.57+0.01$ \\
\hline $\begin{array}{l}\text { Active Imm.+ } \\
\text { Inf. }\end{array}$ & $0.09+0.02$ & $0.15+0.01$ & $0.55+0.02$ & $1.56+0.11$ \\
\hline $\begin{array}{l}\text { Enro.+Inf. } \\
+ \text { Enro. }\end{array}$ & $0.07+.09$ & $0.08+0.01$ & $0.12+0.19$ & $0.71+0.03$ \\
\hline
\end{tabular}

Table 12: Results of serum plate agglutination (SPA) of groups (1-6).

\begin{tabular}{|l|c|c|c|c|c|}
\hline \multicolumn{1}{|c|}{ Age in week } & $\begin{array}{c}\text { No. of chickens } \\
\text { Examined }\end{array}$ & $1^{\text {st }}$ week & $2^{\text {nd }}$ week & $3^{\text {rd }}$ week & $5^{\text {th }}$ week \\
\hline CO. & 5 & 0 & 0 & 0 & 0 \\
\hline CO.+Inf. & 5 & 0 & 0 & $3 / 5$ & $5 / 5$ \\
\hline Inf.+ Pass.Imm.. & 5 & 0 & 0 & $3 / 5$ & $1 / 5$ \\
\hline $\begin{array}{l}\text { Pass.Imm.+ } \\
\text { Inf.+Pass.Imm. }\end{array}$ & 5 & 0 & 0 & $2 / 5$ & $1 / 5$ \\
\hline $\begin{array}{l}\text { Active Imm.+ } \\
\text { Inf. }\end{array}$ & 5 & 0 & $1 / 5$ & $4 / 5$ & $5 / 5$ \\
\hline $\begin{array}{l}\text { Enro.+Inf. } \\
\text { +Enro. }\end{array}$ & 5 & 0 & 0 & $3 / 5$ & $1 / 5$ \\
\hline
\end{tabular}

No. $=$ number

\section{DISCUSSION}

The active vaccination using the F-strain of M.G. was used for controlling the disease. (Levisohn and Kleven, 1981) isolated M.G. from trachea of vaccinated birds up to one year, but their spread was slow. They suggested that the continued presence of non virulent M.G. in the respiratory tract would prevent the localization of the virulent strain. Moreover, it continues stimulating the local immunological response against M.G. in the chicken of flocks (Cummings and Kleven, 1986; Ahmed, 1996). The experimental infection of chickens gr. (2) with M.G. revealed leukocytosis, lymphocytosis, and heterophilia at the end of the $3^{\text {rd }} \& 5^{\text {th }}$ weeks of age. Monocytosis was observed at the end of the $3^{\text {rd }}$ week only. The previous result may be due to the infection in which birds respond to infection with leukocytosis, lymphocytosis heterophilia 
and monocytosis. The avian species responded to wide range of pathogenic agents with leukocytosis, commonly heterophilia (Hawkey, 1983). The principle function of the lymphocytosis is the immunological response to antigens like M.G., such response leads to proliferation and differentiation of the lymphocyte to that is usually manifested by lymphocytosis. The monocyte play an essential role in the immune response after antigenic stimulation, either as phagocytic cells or antigen presenting cells to lymphocytes (Coles, 1986 ).

The lymphopenia usually associated with mycoplasma infection and it may be due to the use of different species of birds, different doses and strains of the microorganism or different routes of infection. The M.G. infection causes highly significant increase in AST, ALT, and AP, these elevation of serum enzymes may be due to the increased cell membrane permeability and destruction and/or necrosis of hepatic cells permitting the intracellular enzymes to escape to the blood (Eisa, 2001; El-shimy, 2002) and non-significant changes in the AST after the oral M.G.. infection (Arafa, 1993).

The M.G. infected gr. (2) showed hyperglobulinemia which lead to hyperproteinemia. The hyperglobulinemia may be due to the immunodefence of the chickens against the organism (Coles, 1986 and 1997). Hypoalbuminemia was encountered at the end of the $5^{\text {th }}$ week only due to inflammation destruction in the liver which is the main source of albumin synthesis in the body (Abou El-Nile, 1997). Nonsignificant changes in the albumin in 10 day old chickens infected with M.G. (Eisa, 2001).

The M.G. infection did not affect the renal tissues consequently, there were non significant changes in the serum creatinine. The kidneys of all infected chickens appeared apparently normal without lesions (Eisa, 2001), while Arafa (1993); Abou El-Nile (1997) and El-shabiny, et al. (1997) observed an increase in the creatinine level after M.G. infection in chickens on the $7^{\text {th }}$ and $8^{\text {th }}$ days of age orally and intranasal respectively. At the $3^{\text {rd }}$ and $5^{\text {th }}$ week of age the serum uric acid was increased in spite of normal kidney which may be due to disturbance in purine metabolism or increase adenosine triphosphate degeneration (ATP) (Dincer et al., 2002).

The passive immunization seems to be one of the most valuable applications of antibodies in which pathogen-specific IgG is administered to individuals for prevention of infectious diseases. Passive immunization differs from active immunization (vaccination) in that the former employs an antibody obtained from other animals. The 
administration of this antibody specific to certain antigens (bacteria, virus and toxin) to individuals orally or parenterally neutralizes the infectious activity or toxicity of the antigen (Yamamoto et al., 1997). The hen's egg yolk contains the immunoglobulin known as IgY (Akita and Nakai, 1992). The ordinary egg yolk has been shown to contain an antibody level up to $15 \mathrm{mg} / \mathrm{ml}$ and is a good potential source of immunoglobulin (Rose et al., 1974). The inoculation of hens with antigens (bacterial or viral) has been shown to generate high titers of specific antibodies in the egg yolk (Polson, 1990). Now the production of immunized egg has become an economical source of antibodies for various application (Song et al., 1985). The employment of the egg yolk antibody in the normal chickens gr. (4) in $1^{\text {st }}$ and $2^{\text {nd }}$ weeks of age, showed non significant changes in the TLC, hrterophils, lymphocytes, eosinophils, monocytes AST, ALT, AP, albumin, uric acid and creatinine. In the $1^{\text {st }}$ week of age, non significant changes were recorded in total proteins globulin. However, significant increase in both total proteins and globulin in response to the injected antibodies was observed in the $2^{\text {nd }}$ week of age. Chickens in grs. ( $\left.3 \& 4\right)$ which infected with M.G. then passively immunized with egg yolk antibodies, revealed leukocytosis, lymphocytosis and monocytosis in addition to heterophilia, there was a significant increase in the AST, ALT, total proteins, globulin and uric acid at the end of the $3^{\text {rd }}$ week of age only. This increase could be due to the infection with M.G. At the end of the $5^{\text {th }}$ week of age and after the last dose of immunization, all the measured parameters returned to nearly the normal values except a significant increase in the total proteins due to increased globulin which could be due to the neutralizing effect of the injected IgY against the M.G.

The IgY obtained from hens immunized with pathogenic bacteria, inhibit the growth of pseudomonas aeruginosa (Sugita-Konishi, et al., 1996), also the oral administration of IgY from chicken egg yolk, has been successfully in preventing many enteric diseases such as enterotoxigenic E. coli and human rotavirus (Ebina, 1996; Sarker, et al., 2001). Malik, et al. (2006) succeeded in control the infectious bursal disease by intraperitoneal injection of egg yolk as a source of antibodies. The active immunized gr. (5) with F-strain of M.G., showed nearly similar pattern of infection in leukogram and proteinogram,in which leukocytosis, heterophilia, lymphocytosis and monocytosis besides hyperproteinemia due to hyperglobulinemia were observed allover the experimental periods. F-strain engulfed by macrophage and then represent the antigen into $\mathrm{T}$-cell which activated and proliferated into the 
cells. Activated T-cell secretes interleukin which stimulate production of inflammatory cells as netrophils, monocytes and lymphocytes. The activation lead to proliferation of the B-lymphocytes which changed to plasma cells to produce immunoglobulin. F-strain vaccine induced leukocytosis, heterophilia, lymphocytes and monocytosis. All the hepatic and renal function parameters were not significantly changed, indicated that the F-strain vaccine protected the liver and kidneys from the side effect of the microbe (Fundenberg, et al., 1976; Coles, 1986; El-shimy, 2002). The F-strain vaccine can produce mild lesions in all examined tissues with no symptoms resulting in less tissue damage followed by faster recovery (Rodriguez and Kleven, 1980; Hildbrand et al., 1983; Dardeer et al., 2004). Live F-strain vaccine provide a reduction in the clinical signs and have been shown to replace endemic strains when used for several times and also capable for eliciting stronger antibody response and providing better protection against air sacculitis, it is able to offer protection against colonized by virulent wild type field strain (Evans et al., 2000). Therefore-strain M.G. vaccine have been used, as a useful part of an eradication program as a viable tool to displace virulent wild type M.G.

The drug therapy is away of controlling the Mycoplasma infection which still plays a major role in decreasing the economic loss due to mycoplasma infection in meat and layer flocks (El-Mahi and Hofstad, 1978; Cummings and Kleven, 1986). The antibiotic medication is much more effective when used prophylatically than when used as treatment. The continuous feed medications is sometimes used, but we should remember that the antibiotic medications is expensive and resistant organisms may develop. Some antibiotics may be toxic if an over dosage is given accidentally and the residues of antibiotics are undesirable in egg or meat for human consumption. Attempts to control mycoplasmosis frequently relied on the intensive and prolonged use of antimycoplasmal drugs (Migaki et al., 1993). The effect of enrofloxacin on leukogram of the healthy non infected chickens, revealed leukopenia, heterophilia and lymopenia at the end of the $1^{\text {st }}$ week of age. these results may be due to drug stress condition as a result of the secretion of adrenocortical hormones that cause dissolution of these cells. After norfloxacin administration leukopenia (Gellert, 1981), leukocytosis or non significant changes in the T.L.C. (Fleischer et al., 2000; Jayakumar et al., 2002; El-kadeem, 2005). In our opinion, such contradiction may be attributed to the time of administration or the difference in species and individual susceptibility. At the end of the $2^{\text {nd }}$ week of age, the 
T.L.C. returned to nearly the normal value. This may be due to the cessation of the drug. The chickens infected with M.G. and treated with enrofloxacin, showed nearly similar picture of leukogram to those in gr. (2) at the end of the $3^{\text {rd }}$ week, this may be due to the effect of microorganism. Non significant changes in leukogram of gr. (6) compared with the infected non treated birds at the end of the $5^{\text {th }}$ week.

The serum AST \& ALT are standard tests for hepatocellular function. Although the AST \& ALT are not liver specific in birds, however the increase in their activities has been associated with hepatocellular damage in birds (Coles, 1986). ALT is more specific than the AST in early hepatocellular damage in which the AST is associated with cell necrosis of many different tissues, either muscular or hepatic. The serum alkaline phosphates activity was increased 5-6 time than the normal with diseases (Coles, 1986). In the present work, the therapeutic dose of enroflxacin induce significant increase in the activities of AST, ALT \& AP in the $1^{\text {st }}$ week of age due to mild toxic effect of the drug metabolites which increase the permeability of the cell membrane increasing hepatic enzymes. The enrofloxacin cause hepatic dysfunction (Halkin, 1988) and elevation of the serum AST, ALT \& AP during treatment then restored its normal value after 2 weeks (Gellert, 1981; Abd El-Alim et al., 2000; El-Kadeem, 2005). In the present work the enrofloxacin induce non significant changes in total proteins, albumin and globulin at the end of the $1^{\text {st }} \& 2^{\text {nd }}$ weeks, these results may be due to the mild and reversible effect of the drug on the liver (Helal et al., 1995; Uyanik et al., 2000). The hyperproteinemia due to hyperglobulinemia in the $3^{\text {rd }} \& 5^{\text {th }}$ week of age after enrofloxacin treatment, may be attributed to the effect of the infection with M.G. and may need long time to return to its normal value. Non significant changes in albumin in gr. (6) compared with gr. (2) at the end of the $5^{\text {th }}$ week indicating favorable response to the treatment (Ibrahim, 1995). The uric acid is the primary catabolic product of protein, non protein nitrogen and purins in the birds (Coles, 1986). The birds are uricotelic and produce uric acid not urea as the major nitrogenous end product of metabolism. The use of enrofloxacin affect on the renal tissue leading to some renal damage (Shimada and Hori, 1992), this renal damage led to increase serum uric acid and creatinine at the end of the $1^{\text {st }}$ week of age and were not significantly changed at the end of $2^{\text {nd }}$ week. This means that the effect of the drug is reversible. The serum creatinine is a major non-protein nitrogen compound of avian blood (Bell and Freeman, 1971) and become elevated in the birds with renal diseases due to nephrotoxic 
drug, but less than the uric acid (Galvin, 1980). Hyperuricemia in the birds occurs with starvation, gout massive tissue destruction and renal diseases (Coles, 1986). Hyperuricemia and increase in creatinine level in the $1^{\text {st }}$ week of age was due to treatment with enrofloxacin. Kobayashi, et al. (2004) and El-Kadeem (2005) noticed hyperuricemia and increased creatinine level after enrofloxacin treatment and Kamel and Abd El-Aziz (2002) noticed decrease in uric acid and increase in creatinine after I/M injection of norfloxacin in turkeys. The serum uric acid nearly regained its normal value in the $5^{\text {th }}$ week of age after treatment, this finding may be due to antimycoplasmal activity of the drug. The enrofloxacin induce significant increase in the uric acid and creatinine, these deviations regained their normal one week post-treatment (Khodary and El sayed, 1997).

The serological tests is the preferred method of testing M.G. antibodies because of the easy of obtaining sera, the sensitivity and reproducibility of the assays (Spencer et al., 2002). The antimycoplasmal antibodies were detected in the experimentally infected chickens of gr. (6) on the $5^{\text {th }}$ day post-infection. The immunotherapeutic treatment using the antimycoplasmal gallisepticum egg yolk antibodies (IgY), results in non significant decrease in the antibody response on the $35^{\text {th }}$ day in gr. (3) compared with the infected non treated gr. The chicken of gr. (4) which were passively immunized revealed highly significant increase of the ELISA titer in the $2^{\text {nd }}$ week, this result could be due to the injected antibodies. The level of antibodies was increased in gr. (4) after the infection and was still increased specially in the $3^{\text {rd }}$ week, compared with infected non treated gr. The decreased of antibody level in the $5^{\text {th }}$ week was mostly due to reduced colonization of the M.G. by the passive immunization using egg yolk antibodies specific for M.G.

The vaccine stimulat the humeral response in the chickens of gr. (5) by increase in the antibody level gradually before and after infection. The live M.G. F-strain vaccine is estimated to be highly immunogenic (Abd El-Motelib and Kleven, 1993; Ferguson et al., 2004). Since the level of protection by live M.G. vaccines is directly correlated with the virulence of the vaccine strain (infectivity, pathogenicity and immunogeicity) F-strain elicited stronger antibody response and provide protection against colonization by more virulent strains (Levisohn, 1984; Cummings and Kleven, 1986). The antibodies in the sera of birds vaccinated with TS-11 and challenged with M.G. began with low titer and increased gradually till the $3^{\text {rd }} \& 4^{\text {th }}$ week post-challenge (Noormohammad et al., 2002). 
No positive results of the antibody titer were observed till the end of the $2^{\text {nd }}$ week in gr. (6). After challenge and treatment with enrofloxacin the antibody titer increased in the $3^{\text {rd }}$ week due to challenge. It was decreased in the $5^{\text {th }}$ week in comparison with the infected non treated gr., this decrease may be due to the enrofloxacin effect on the M.G. The infection with M.G. is not completely prevented and subsequently the flock remain at risk. Also the continuous medication has the potential for reducing the M.G. tracheal population. The deleterious effect of the mycoplasma on chickens, leads to the activation of the immune system of the birds to produce more lymphocytes, leukocytes and round cells to overcome the infection (Ahmed, 2004). The serum plate agglutination test (SPA) is more rapid test detecting mycoplasma infection, therefore preferably used as screening test (Kleven et al., 1984; Yoder, 1989; El-shimy, 2002; Dardeer et al., 2004). The active infection started with agglutination antibodies which appeared early in the serum (one week after infection) and remained detectable for 30 days (Rodriguez and Kleven, 1980). In the present work, the SPA revealed $3 / 5$ positive result, in the infected chickens of gr. (2) on the $5^{\text {th }}$ day post-infection and reached its highest level on the $35^{\text {th }}$ day of age. Concerning the immunotherapeutically treated grs. ( $3 \& 4)$, the positive results of the SPA in the $3^{\text {rd }}$ week of age, were $3 / 5 \& 2 / 5$ respectively, then reached $1 / 5$ for both grs. On the $35^{\text {th }}$ day of age. This decreased could be due to the passive immunization. A gradual positive result of the SPA test was found in the $2^{\text {nd }} \& 3^{\text {rd }}$ weeks post active vaccination of gr. (5) and reached its maximum level in the $5^{\text {th }}$ week and this may be attributed to the effect of the F-strain vaccine. Regarding to the enrofloxacin treated gr., the results of the SPA test on the $5^{\text {th }}$ day post-infection was $3 / 5$, however it dropped to $1 / 5$ in the $5^{\text {th }}$ week. this decrease could be due to the effect of enrofloxacin on the M.G. The treatment of M.G. with antimycoplasmal drugs may also prevent significant immune response and make it difficult to isolate the microorganism giving false impression that the flock is free from infection.

It could be concluded that M.G. induced hematological, biochemical and serological changes. The vaccination is the best method to control mycoplasmosis in chickens, as it stimulated the immune defense without any side effect. The passive immunization came next and the last was the treatment with antimycoplasmal drugs.

\section{REFERENCES}


Abd El-Alim, F.A.; Amer, M.S.; Ramadan, O.E.; Mohamed, T.A. and Edreis, N.O. (2000): Efficacy of ofloxacin against induced colibacillosis in broiler chickens. J. Vet. Med. Res., 2(1): 113123.

Abd El-Motelib, T.Y. and Kleven, S.H. (1993): Comparative study of Mycoplasma gallisepticum vaccines in young chickens. Avian Dis., 37(4): 981-987.

Abou, El-Nile, M.O. (1997): Some pharmacological studies on norfloxacin in experimental animals. M.V.Sc. Thesis, Pharmacology Fac. Vet. Med., Zag. Univ.

Adler, H.E. and Yamamoto, R. (1956): Preparation of new PPLO antigen for the diagnosis of CRD by agglutination test. Am. J. Vet. Res., 290-293.

Ahmed, A.M. (1996): Control of avian Mycoplasma. Ph. D. Thesis, poultry and rabbit diseases, Fac. of Vet. Med., Assiut Univ.

Ahmed, N.A.M. (2004): Experimental pathological studies on some drugs of quinolones group in broiler chicks. M.V.Sc. Thesis, Pathology Dept. Vet. Med., Zag. Univ.

Akita, E.M. and Nakai, S. (1992): Immunoglobulin from egg yolk: isolation and purification. J. Food Sci., 57: 626- 634.

Arafa, M.M. (1993): Comparative pathological and clinicopathological studies on Mycoplasma gallisepticum in chickens and turkeys M.V.Sc., Thesis, Pathology Dept., Fac. Vet. Med., Zag. Univ.

Belfeild, A. and Goldberg, D.M. (1971): Revised assay for serum alkaline phosphates activity using 4-amino antipyrine. Enzyme, 12: 561-573.

Bell, D.J. and Freeman, B.M. (1971): Physiology and biochemistry of the domestic fowl. Volume 1, Academic Press, London, and New York.

Calnek, B.W.; Barners, H.J.; Beard, C.W.; McDougakd, L.R. and Saif, Y.M. (1997): Diseases of poultry, $10^{\text {th }}$ ed editorial board for the American Association of avian pathologists, Mosby-Wolfe, London, Philadelphia.

Charmbach, A. (1985): The practice of quantitative gel -electrophoresis. VCH Press, Weihem. 23.

Clyde, W.A. (1983): Methods in Mycoplasma morphology: Growth inhibition test in Methods in Mycoplasmology, Vol. 1, 40 Academic press. New York.

Coles, E.H. (1986): Veterinary Clinical Pathology $4^{\text {th }}$ Ed. WB Saunders Company, Philadelphia, London, Tokyo, Hong Kong. 
Coles, E.H. (1997): Aids to Diagnosis .In: Avian Medicine and Surgery. $2^{\text {nd }}$ ed., J. B. Sutton JP MRCVS St. Swift MA, Vet. MB Cert. SAC.

Cummings, T.S. and Kleven, S.H. (1986): Evaluation of protection against Mycoplasma gallisepicum infection in chickens vaccinated with F-strain of Mycoplasma gallisepticum. Avian Dis., 30(1): 169-171.

Dardeer, M.A.; Yousseif, A.I. and Tantawy, L.A. (2004): Pathological studies on chickens experimentally infected with field strain of Mycoplasma gallisepticum and vaccinated with Mycoplasma gallisepticum vaccine. Minufiya Vet. J., 3(2): 547- 559.

Dincer, E.; Dincer, A. and Levinsan, J. (2002): Clinical significance of serum uric acid. Cleveland Clinic Journal of Medicine, 69(8): 3-5.

Doumas, B.T. (1971): Colorimetric determination of serum albumin. Clin. Chem. Anta., 400-403.

Doumas, B.T. and Biggs, H.G. (1972): Determination of serum globulin. In: Standard Methods of Clinical Chemistry. Vol. 7 edited by G.R. Cooper, New York Academic Press.

Ebina, T. (1996): Prophylaxis of rotavirus gastroenteritis using immunoglobulin. Arch Virol. Supp., 12: 217- 223.

Eisa, A.M.A. (2001): Clinicopathological studies on the effect of aivlosin as antimycoplasmal drug in chickens. Ph.D. Thesis, Clinical Pathology Dept., Faculty of Vet. Med., Zag. UNiv.

El-Kadeem, A.E.M. (2005): Pharmacological studies of gentamicin and ciprofloxacin in collibacillosis in chickens. M.V.Sc. Thesis, Pharmacology Dept., Fac. Of Vet. Med., Zag.Uinv.

El-Mahi, M.M. and Hofstad, M.S. (1978): Prevention of egg transmission of Mycoplasma meliagridis by antibiotic treatment of naturally and experimentally infected turkey eggs. Avian Dis., 23: 88-94.

El-Shabiny, L.M.; El-Baguory, A.M. and Abdel-Megid, F. (1997): Blood Biochemical in association with Mycoplasma meleagridis infection in turkeys. XIth International Congress of the World Veterinary Association. Budapest, Hungary. 18-22, August: 227.

El-Shimy, A.A. (2002): Clinicopathological studies on living and dead Mycoplasma vaccines in poultry. M.V.Sc. Thesis, Clinicalpathology Dept. Fac. Vet. Med., Cairo Univ. 
Engvall, E. and Perlmann, P. (1981): Enzyme-Linked immunosorbant assay (ELISA). Quantitative assay of immunoglobulin. Immunochem., 8: 871-874

Evans, R.D.; Trites, J.D.; and Cochrane, R.L. (2000): Field isolation of Tylosine premix in layers previously vaccinated with a live M.G. vaccine. Elanco Animal Health, Green field IN46140, USA.

Ferguson, N.M.; Leiting, V.A. and Kleven, S.H. (2004): Safety and efficacy of the virulent Mycoplasma gallisepticum strain K5054 as a live vaccination in poultry. Avian Dis., 48(1): 9199.

Fisher, R.A. (1953): Statistical methods for research workers. Oliver and body Ltd. Edinburgh and London.

Fleischer, L.G.; Gerber, G.; Liezenga, R.W.; Lippert, E.; Scholl, M.A. and Wetphal, G. (2000): Blood cells and plasma proteins of chicken fed a diet supplemented with (1->3), (1->^)-beta-Dglucan and enrofloxacin. Arch Tierernahr., 53(1)59-73.

Fossati, P. (1980): Colorimetric method for determination of serum uric acid. Clin. Chem., 26(2): 227.

Fundenberg, H.H; Stites, J.I. and Wells, J.V. (1976): Basic and Clinical Immunology. Lithographed in USA, 98-101.

Galvin, C.E. (1980): Laboratory Diagnostic Aids in Pet Birds Practice. In: Proceeding of American Animal Hospital Association. South Bend, IN. P: 41.

Gellert, Z.M. (1981): DNA topoismerases. Annu. Rev. Biochem., 50: 879-910.

Halkin, H. (1988): Adverse effects of fluoroquinolones. Rev. Infec. Dis., 10: 258-261.

Hawkey, C.M. (1983): Hematological findings in healthy and sick African Grey Parrot. Vet. Rec.,111: 580-582.

Helal, A.D.; El-Ezzawy, M.H.; Mousa, S.M. and Metwelly, M.U. (1995): Effects of new antibacterial drugs, enrofloxacin on histology Blood biochemical parameters of native broilers chickens. Zag. Vet. J. 23(3): 55-61.

Henry, R.J. (1974): Colorimetric method for determination of serum creatinine.Clinical chem., Principles and Techinques. $2^{\text {nd }}$ ed. Harper and Row: 525.

Henry, R.J. (1979): Colorimetric method for determination of serum total protein. Clinical Chem. Harper and Row Publishers, New York, 181. 
Hildbrand, D.G.; Page, D.E. and Berg, J.R. (1983): M.G. Laboratory and field studies evaluation the safety and efficacy of an inactivated M.G. battering. Avian Dis., 27: 792-802.

Ibrahim, S.A.R. (1995): Effect of enrofloxacin on the immune response of chickens under vaccination. MVSC. Thesis, Pharmacology Dep., of Vet. Med. Zag. Univ.

Jayakumar, K.H.; Krishnappa, G.; Sastry, K.N. and Narayana, K. (2002): Effect of ciprofloxacin on specific immune response in rabbits. Indian J. Exp. Biol., 40(1): 111-114.

Jensenius, J.C. and Koch, C. (1997): Antibodies packaged in eggs. In: Johnstone, A.P. and Turner, M.W. (eds). Immunochemistry (a practical Approach). Oxford Univ. Press.

Jordan, F.T. (1979): Avian Mycoplasmas. In: The Mycoplasmas, Vol. II, Tully, J.G. and Whitcob, R.F., Eds. Academic Press, New York, USA, and London, UK, 1-4.

Kamel, A.A. and Abd El-Aziz, A.H. (2002): Some studies on norfloxacin residues and its effect on liver and kidney functions in Turkeys. J. Egyp. Vet. Med. Association., 62(5): 137-147.

Khodary, R.M. and El-Sayed, E.M. (1997): Treatment of duclking salmonellosis by enrofloxacin. Assiut. Vet. Med. J., 36(72): 262-268.

Kempf, I.; Gesbert, M.; Bennejean, G.; and Cooper, A.C. (1992): Efficacy of danofloxacin in the therapy of experimental mycoplasmoses in chicks. Research in Vet. Sci., 53 (2): 257259.

Kleven, S.H. (1990): Advances in the control of avian MycoplasmaVII. Semimria Internacional de pathologia avian en Espanol, Athens, Georgia, U.S.A.,1-9.

Kleven, S.H.; Glisson, J.R.; Lin, M.Y. and Talkington, F.D. (1984): Bacterins and vaccines for the control of M.G. Isr. J. Med. Sci., 20(10): 989-991.

Kobayashi, C.; Yokoyama, H.; Van Nguyen, S.; Kodama, Y.; Kimata, T. and Izeki, M. (2004): Effect of egg yolk antibody on experimental cryptosporidium parvum infection in scid mice. Vaccine, 23: 232-235.

Levisohn, S. and Kleven, S.H. (1981): Vaccination of chickens eith nonpathogenic Mycoplasma gallisepticum as a means for displacement of pathogenic strains. Isr. J. Med. Sci., 17(\&): 669-673. 
Levisohn, S. (1984): Early stage in the interaction between Mycoplasma gallisepticum and the chicken trachea, as related to pathogenicity and immunogenicity. Isr. J. Med. Sci., 20(10): 982-984.

Levisohn, S. and Kleven, S.H. (2000): Avian Mycoplasmoses (Mycoplasma gallisepticum. In Process Citation). Rev. Sci. Tech., 19(2): 425-442.

Lowry, O.H.; Rosenbrough, N.J.; Farr, A.L. and Randall, R.J. (1951): Protein measurement with foline phenol reagent. J. Biol. Chem., 193: 265.

Malik, M.W.; Ayub, N. and Qureshi, I.Z. (2006): Passive immunization using purified IgY against infectious bursal diease of chickens in Pakistan. J. Vet. Sci., 7(1): 43-46.

Margaret, A. and Richard, E.S. (2000): Passive immunity in prevention and treatment of infectious diseases. Clinical Microbiology Review, 13(4): 602-614.

Migaki, T.T.; Avakin, A.P.; Brnes, H.J.; Tanner, A.C. and Magnonigle (1993): Efficacy of danofloxacin and tylosin in the control of Mycoplasmosis in chicks infected with field isolates of Mycoplasma gallisepticum. Avian Dis., 37: 508-514.

Noormohammadi, A.H.; Browning, G.F.; Cowling, P.J.; O'Roureke, D.; Whithear, K.G. and Markham, P.F. (2002): Detection of antibodies to M.G. Ts-11 enzyme-linked Immunosorbant assay. Avian Dis., 46(2): 405-411.

Nutt, M.P. and Herrick, C.A. (1952): A new blood diluent for counting erythrocytes and leucocytes of chicken. Poult. Sci., 31: 735738.

Patten, B.E.; Higgins, P.A. and Whithear, K.G. (1984): A Ureae-ELISA for detection of Mycoplasma infection in poultry. Aust. Vet. J., 16(5): 151-155.

Poloson, A. (1990): Isolation of IgY from the Yolks of eggs by chloroform polyethylene glycol Procedures. Immunol. Invest., 19: 253-258.

Reitman, S. and Frankel, S. (1957): Colorimetric method for determination of serum transaminase activity. Am. J. of Clinical Pathology, 28: 65-68.

Robert, D.H.; James, D.T. and Robert, L.C. (2001): Field evaluatiuon of Tylosin premix in layers previously vaccinated with a live M.G. vaccine. Elanco Animal Health, West Main Street, Greenfield IN., 40-46. 
Rodriguez, R. and Kleven, S.H. (1980): Pathogenicity of two strains of Mycoplasma gallisepticum in broilers. Avian Dis., 24(4): 800807.

Rose, M.E.; Orlans, E. and Buttress, N. (1974): Immunoglobulin classes in the hen's egg: their segregation in yolk and white. Eur. J. Immunol. 4: 521.

Sarker, S.A.; Casswall, T.H.; Jone, L.R.; Hog, E.; Hossain, I.; Fuchs, G.J. and Hammarstrom, L. (2001): Randomized placebocontrolled clinical trail of hyper immunized chick egg yolk immunoglobulin in children with rotavirus diarrhea. J. Pediatr Gastroenterology Nutr., 32(1); 19-25.

Shimada, J. and Hori, S. (1992): Adverse effects of fluoroquinolones. Prog Drug Research, 38: 135-143.

Song, C.S.; Yu, J.K. and Bai, D.H. (1985): Antibodies to the alphasubunit oh insulin receptor of eggs of immunized hens. J. Immunol., 135: 3354-3359.

Spencer, D.L.; Kurth, K.T.; Menon, S.A.; Van Dyk, T. and Minion, F.C. (2002): Cloning and analysis of the gene for a major surface antigen of Mycoplasma gallisepticum. Avian Dis., 46: 816-825.

Stipkovits, L. (1997): Study of the effect of imodulen (IM-104) on chickens experimentally infected with M.G. Vet. Med. Res. Institute, Budapest, Hungary.

Sugita,-Konishi, Y.; Shibata, K.; Yun, S.S.; Hara-Kudo, Y.; Yamaguchi, K. and Kumagai, S. (1996): Immune function of immunoglobulin Y isolated from egg yolk of hens immunized with various infectious bacteria. Bio Sci. Biotechnol Biochem., 60 (5): 886-888.

Towbin, H.; Staehlin, T. and Gordon, J. (1979): Electrophoretic transfer of proteins from polyacrylamide gels to nitrocellose sheets: Procedure and some applications. Proc. Natl. Acad. Sci., USA. $76 ; 4350$.

Uyanik, F.; Liman, B.C. and Liman, N. (2000): The effect of danofloxacin on some biochemical parameters and liver in broilers. Vet. Bull., 70(3): 358.

Whithear, K.G. (1996): Control of avian mycoplasmosis by vaccination Rev. Sci. Tech., 15(4): 1527-1553.

World organization for Animal Health (2007): Manual of diagnostic tests and vaccines. Paris: OIE; Avian Mycoplasmosis. Mycoplasma gallisepticum. 
Yamamoto, T.; Junela, L.R.; Hatta, H. and Kim, M. (1997): Hens eggs Their Basic and Applied Science. CRC. Press, Inc.

Yoder, H.W. (1989): Non specific reactions to Mycoplasma serum plate antigens induced by inactivated poultry disease vaccines. Avian Dis., 33: 60-68. 